\title{
Iron deficiency anemia and its treatment - reply
}

\section{Rodolfo Delfini Cançado}

Hematology and Oncology Department, Faculdade de Ciências Médicas da Santa Casa de São Paulo, São Paulo, SP, Brazil

Conflict-of-interest disclosure:

The authors declare no competing financial interest

Submitted: 3/28/2011

Accepted: 4/2/2011

\section{Corresponding author:}

Rodolfo Delfini Cançado

Hemocentro da Santa Casa de São Paulo

Rua Marquês de Itú, $579-3^{\circ}$ andar

01223-001 - São Paulo, SP, Brazil

Phone: $55112176-7255$

rdcan@uol.com.br

www.rbhh.org or www.scielo.br/rbhh

DOI: $10.5581 / 1516-8484.20110064$
From a practical standpoint, it is recommendable to adopt some measures in order to succeed in minimizing the adverse events and improve adherence to oral iron supplementation treatment, such as splitting the recommended daily dose in two or three smaller doses, counseling the patient to take the medication during or after meals (in these cases, the reduction in the amount of iron absorbed can be offset by increased adherence and duration of treatment) and initiating therapy with doses lower than recommended, i.e. 40 to $80 \mathrm{mg}$ /day and gradually increase them, depending on the tolerance of the patient. ${ }^{(1-4)}$

It is well known that when administering daily doses of elemental iron below $60 \mathrm{mg}$, the frequency and intensity of adverse events observed are similar between individuals taking placebo and iron salts. Thus, clinical studies have used iron sulfate in different treatment regimens such as: $25 \mathrm{mg}$ of elemental iron once per week; ${ }^{(4)} 60 \mathrm{mg}$ of elemental iron once daily or twice per week; ${ }^{(5)}$ and $60 \mathrm{mg}$ of elemental iron once weekly or once per day. ${ }^{(6)}$ The results clearly demonstrated that adherence is better when using smaller doses at longer intervals, however, the therapeutic success is not what was expected or the time required to achieve the expected result is much longer (weeks or months).

Undoubtedly, an intermittent administration of oral iron should be recommended as a way of improving treatment compliance and reduce dropout rates to treatment, especially in pregnant women.
Also elderly patients have a higher incidence of adverse events when treated with oral iron at the recommended therapeutic dose. In these cases, lower doses, even $15 \mathrm{mg}$ of elemental iron per day may be effective in cases of mild anemia due to lower adverse events. $^{(4)}$

\section{References}

1. Cançado RD, Lobo D, Friedrich JR. Tratamento da anemia ferropriva com ferro por via oral. Rev Bras Hematol Hemoter. 2010;32 (Supl.2):114-20.

2. Alleyne M, Horne MK, Miller JL. Individualized treatment for iron-deficiency anemia in adults. Am J Med. 2008;121(11):943-8.

3. Hallberg L, Ryttinger L, Solvell L. Side-effects of oral iron therapy. A double blind study of different iron compounds in tablet form. Acta Med Scand Suppl.1996;459:3-10.

4. Rimon E, Kagansky N, Kagansky M, Mechnick L, Mashiah T, Namir M, et al. Are we giving too much iron? Low-dose iron therapy is effective in octogenarians. Am J Med. 2005; 118(10):1142-7. Comment in: Evid Based Med. 2006;11(3):89. ACP J Club. 2006;144 (3):71.

5. Lopes MC, Ferreira LO, Batista FM. Uso diário e semanal de sulfato ferroso no tratamento de anemia em mulheres no período reprodutivo. Cad Saúde Pública. 1999;15(4):799-808.

6. Coplin M, Schuette S, Leichtmann G, Lashner B. Tolerability of iron: a comparison of bisglycino iron II and ferrous sulfate. Clin Ther. 1991;13(5):606-12. 